\title{
Correction to: Mobile Link - a theory-based messaging intervention for improving sexual and reproductive health of female entertainment workers in Cambodia: study protocol of a randomized controlled trial
}

Carinne Brody ${ }^{1}$, Sovannary Tuot ${ }^{2}$, Pheak Chhoun ${ }^{2}$, Dallas Swendenman ${ }^{3}$, Kathryn C. Kaplan² and Siyan Yi ${ }^{1,2^{*}}$

\section{Correction to: Trials}

https://doi.org/10.1186/s13063-018-2614-7

After publication of our article [1] we became aware that several sections of text in our Methods section were copied from a previously published article [2]. We would like to formally apologize and give credit to the authors of that article [2]: Chris Smith, Uk Vannak, Ly Sokhey, Thoai D Ngo, Judy Gold, Khemrin Khut, Phil Edwards, Tung Rathavy and Caroline Free.

\section{Author details \\ ${ }^{1}$ Public Health Program, College of Education and Health Sciences, Touro University California, Vallejo, CA, USA. ${ }^{2}$ KHANA Center for Population Health, Research, No. 33, Street 71, Phnom Penh, Cambodia. ${ }^{3}$ Department of Psychiatry and Biobehavioral Sciences, University of California, Los Angeles, CA, USA.}

Received: 30 November 2018 Accepted: 30 November 2018 Published online: 13 December 2018

\section{References}

1. Brody C, et al. Mobile Link - a theory-based messaging intervention for improving sexual and reproductive health of female entertainment workers in Cambodia: study protocol of a randomized controlled trial. Trials. 2018;19: 235. https://doi.org/10.1186/s13063-018-2614-7.

2. Smith C, Vannak U, Sokhey L, Ngo TD, Gold J, Khut K, et al. MObile Technology for Improved Family Planning Services (MOTIF): study protocol for a randomized controlled trial. Trials. 2013;14:427.

\footnotetext{
* Correspondence: siyan@doctor.com

${ }^{1}$ Public Health Program, College of Education and Health Sciences, Touro University California, Vallejo, CA, USA

${ }^{2}$ KHANA Center for Population Health, Research, No. 33, Street 71, Phnom

Penh, Cambodia

Full list of author information is available at the end of the article
}

(c) The Author(s). 2018 Open Access This article is distributed under the terms of the Creative Commons Attribution 4.0 International License (http://creativecommons.org/licenses/by/4.0/), which permits unrestricted use, distribution, and reproduction in any medium, provided you give appropriate credit to the original author(s) and the source, provide a link to the Creative Commons license, and indicate if changes were made. The Creative Commons Public Domain Dedication waiver (http://creativecommons.org/publicdomain/zero/1.0/) applies to the data made available in this article, unless otherwise stated. 